\title{
Evolving closure criteria throughout the life of mine
}

\author{
D.V. Koontz Aquaterra Consulting Pty Ltd, Australia
}

\begin{abstract}
Closure criteria is a term broadly used to describe an agreed standard or level of performance which demonstrates successful closure of a site (DITR, 2006). The development of appropriate and practicable completion criteria must be an evolving process over the life of a mining project based on the most up-todate knowledge of site-specific conditions and the status of the operations. Regulators and other interested parties often expect that final detailed completion criteria, in some cases closure plans, can be developed at the initial environmental impact assessment (EIA) phase as a condition of approval. In reality, only broad closure objectives, design criteria and constraints, and conceptual closure activities can be identified at such an early stage of project planning as only limited information is available with regard to material characteristics and advanced design for post-mining landforms.

The approvals process usually coincides with the later stages of feasibility studies to conform to overall development schedules. In many cases environmental approval needs to be confirmed before committing large sums of capital for a project to move forward with detailed design studies. At the definitive feasibility stage mineral resources have been identified, a preliminary mine schedule has been determined and process testwork has been completed to the point of providing a reasonable level of project design and cost estimate. However, there is still much work to be done in refining the detailed design.

Telling the regulators what they want to hear to gain approvals, rather than setting the most appropriate criteria for the site-specific circumstances is usually counter-productive for long-term closure management. In such cases companies and consultants are often making their best guess at how the project will pan out and nominate de facto completion criteria which may ultimately be incorrect for the project outcomes. Experience has shown across many sites that the final post-mining rehabilitated landforms bear little resemblance to those originally defined by detailed completion criteria during EIA. This also discourages adaptive management which is defined as a systematic process for continually improving policies and practices by learning from the outcomes of operational programmes (DITR, 2006).
\end{abstract}

This paper will consider the levels of detail for completion criteria which is appropriate for each phase during the life of a mining operation.

\section{Introduction}

A typical mining project progresses through various stages of development starting from gathering information at the acquisition and exploration phases, to developing a concept and design during the feasibility phases, through to construction, operations, then finally closure and decommissioning (Figure 1). While closure needs to be considered from the very outset of the project, the level of certainty with regard to what can be achieved at closure is limited by the project detail defined at any point during the mine life. 


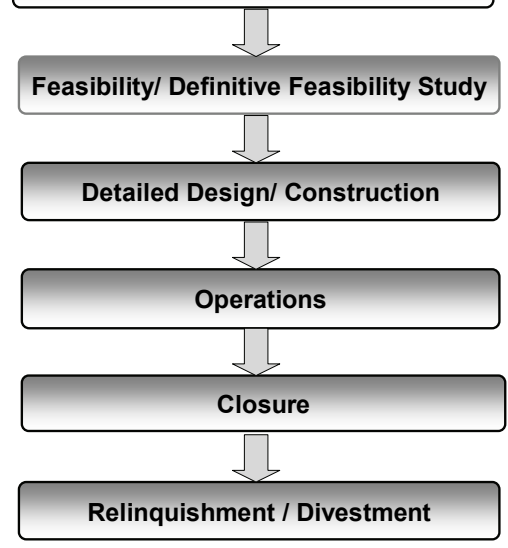

Figure 1 Typical phases of development of mining projects

\section{Closure criteria for feasibility, planning and development phases}

\subsection{Acquisition and exploration phases}

The level of certainty regarding closure implications is highly variable at the acquisition stage of a project and is largely dependent on whether the property is a greenfields or brownfields site. A due diligence review is usually undertaken to assess the potential value of the property based on existing information including previous activities, prospectivity, development potential and likely environmental sensitivities relating to the future development.

A greenfields site means the area has previously been subjected to no or very little exploration or development activity. Closure issues to be considered are limited to the existing land uses and sensitivity of the environment with respect to any future exploration or development activity that may occur.

Brownfields mine sites vary from areas that have been subjected to intensive exploration to those where previous mining and processing has been undertaken. Closure considerations in this context are dependent on the nature and status and of the previous activity, as well as the ongoing development options.

Further development of a brownfields site may present opportunities to fix some problems of the past though adopting a new approach to the overall site closure that is integral with the future development. Therefore, closure criteria adopted for the previous activities will need to be reviewed to ensure that they are still appropriate. Appropriate closure criteria are directly related to the level of knowledge at hand for any given site. At the point of acquisition closure criteria would be mainly in the form of broad closure objectives, or outcomes to be achieved, rather than specific measurable criteria.

The main benefit of setting broad closure objectives at the acquisition and exploration phases of the project is to identify constraints that need to be considered in the development of concepts for future development options (Table 1). In the case of a brownfields site, identifying such closure objectives when undertaking due diligence reviews for acquisition will all assist in identifying costs and liabilities that may be associated with the property. 
Table 1 Acquisition and/or exploration phase - closure objectives and constraints

\begin{tabular}{|c|c|c|}
\hline Context & Closure Objectives & Closure Constraints \\
\hline \multirow[t]{3}{*}{ Biophysical } & $\begin{array}{l}\text { Establish post-mining landforms that will remain in a } \\
\text { safe, stable and non-polluting condition and are } \\
\text { aesthetically compatible with the surrounding } \\
\text { landscape. }\end{array}$ & $\begin{array}{l}\text { - Existing topography. } \\
\text { - Drainage regime. } \\
\text { - Waste materials characteristics. }\end{array}$ \\
\hline & $\begin{array}{l}\text { Minimise impacts on natural drainage systems and } \\
\text { minimise erosion and sediment release to the } \\
\text { environment. }\end{array}$ & $\begin{array}{l}\text { - Existing drainage regimes and } \\
\text { climatic conditions. }\end{array}$ \\
\hline & $\begin{array}{l}\text { Minimise impacts on protected and/or sensitive } \\
\text { vegetation, flora and fauna. }\end{array}$ & $\begin{array}{l}\text { - Existing vegetation } \\
\text { communities and flora and } \\
\text { fauna species present. }\end{array}$ \\
\hline \multirow[t]{2}{*}{ Land use } & $\begin{array}{l}\text { Maximise future land use options with consideration } \\
\text { of the existing land use. }\end{array}$ & $\begin{array}{l}\text { - Existing land use and/or } \\
\text { tenure. } \\
\text { - Regional/local planning. } \\
\text { - Safety implications. } \\
\text { - Aesthetic implications. }\end{array}$ \\
\hline & $\begin{array}{l}\text { Establish sustainable vegetation communities } \\
\text { consistent with an agreed post-closure land use. }\end{array}$ & $\begin{array}{l}\text { - Existing vegetation. } \\
\text { - Existing land use. } \\
\text { - Climate. }\end{array}$ \\
\hline \multirow[t]{3}{*}{$\begin{array}{l}\text { Community/ } \\
\text { stakeholders }\end{array}$} & $\begin{array}{l}\text { Decommissioning and closure options to take } \\
\text { stakeholder interests into consideration. }\end{array}$ & - Stakeholder expectations. \\
\hline & $\begin{array}{l}\text { Minimise the impact of the post-closure landforms on } \\
\text { the local community. }\end{array}$ & $\begin{array}{l}\text { - Proximity to community and/or } \\
\text { sensitive premises. }\end{array}$ \\
\hline & $\begin{array}{l}\text { Relinquish the site in a condition that minimises risks } \\
\text { to human health and the environment. }\end{array}$ & $\begin{array}{l}\text { Potential contaminants that } \\
\text { may be associated with } \\
\text { minerals/wastes or process. }\end{array}$ \\
\hline Economic & $\begin{array}{l}\text { Minimise adverse impacts on local and regional } \\
\text { economies at closure. }\end{array}$ & - Existing economic activities. \\
\hline
\end{tabular}

\subsection{Feasibility studies}

Feasibility studies usually progress through a number of stages where increasing levels of certainty are applied to resource evaluation and engineering design. The following sections discuss typical phases of feasibility studies with respect to evolving closure criteria.

\subsubsection{Pre-feasibility and feasibility studies}

A pre-feasibility study is usually the starting point for a project development following an indication from the exploration programme that an economic orebody exists. The pre-feasibility study deals mainly with development concepts and methodologies based on experience with similar projects. The relative level of accuracy applied for a pre-feasibility study typically ranges between $\pm 25-50 \%$ depending on levels of risk associated with the potential development and financial arrangements. If the pre-feasibility study indicates that the project is likely to be economic, then funding is committed to more advanced exploration and commencement of a feasibility study.

The pre-feasibility and feasibility stages usually provide a basis for preliminary scoping of the project to determine potential risks to environmental aspects of the site and priorities for studies to be undertaken for EIA and development of management measures which include closure activities. At this stage the broad 
closure objectives developed at the acquisition/exploration phase (Table 1) should be reviewed and refined to consider information gaps and the work required to improve the level of certainty.

\subsubsection{Definitive/bankable feasibility study}

The definitive or bankable feasibility study is often the first stage in the planning and development process where a conceptual closure plan can be developed based on a reasonable level of design criteria. The EIA and approval processes usually coincide with the definitive feasibility study to conform to overall development schedules. In many cases, environmental approval needs to be confirmed before committing large sums of capital for a project to move forward with detailed engineering design studies and procurement.

During the definitive feasibility stage most of the baseline environmental studies are completed; mineral resources are identified to $\mathrm{JORC}^{1}$ compliance; a preliminary mine schedule is determined; and processing testwork completed to a point of having a process flow-sheet. Stakeholder consultation should also be undertaken during this phase to determine community and government expectations for closure outcomes.

The relative level of accuracy for the project design and cost estimates at the completion of the definitive feasibility study is usually around $\pm 10-25 \%$ depending on levels of risk with a potential development and financial arrangements. However, the project is still at a concept level and there is still much work to be done in refining the detailed design. Consistent with the Strategic Framework for Mine Closure (ANZMEC and MCA, 2000) it is appropriate to develop a conceptual closure plan at this time.

\subsubsection{Conceptual closure plan}

Building on broad objectives identified during the earlier phases a developer can begin to identify relevant closure activities to be incorporated into the detailed engineering design. The Strategic Framework for Mine Closure (ANZMEC and MCA, 2000) suggests that the conceptual closure plan should include broad land use objectives and indicative closure costs. Although project design cost estimates from the definitive feasibility study may be in the $\pm 10-25 \%$ range, closure cost estimates are still likely to be highly variable (e.g. $\pm 50 \%$ ) as these are not based on actual operational experience.

The experience of many who have worked on mining projects from inception to closure will attest that most projects at the end of the mine life are vastly different from what was originally proposed. Similarly, while waste materials characterisation may have been undertaken based on using limited drill samples, this does not always provide an accurate indication of how these materials will behave in a constructed waste rock dump. It is therefore essential that any mine closure criteria that are set at the pre-development phase are flexible enough to allow for adaptive management during the project life (Table 2). Regulators must recognise that this is the reality of mining developments and accept that closure objectives, design criteria and conceptual closure activities are the most appropriate form of closure criteria at the pre-development approvals phase. Trying to develop specific criteria such as diversity and density of flora species on rehabilitated landforms, prior to development, is simply not practical at the EIA phase in most cases.

\footnotetext{
${ }^{1}$ Australasian Joint Ore Reserves Committee (JORC). The JORC Code for Reporting of Mineral Resources and Ore Reserves is widely accepted as a standard for professional reporting purposes.
} 
Table 2 Definitive feasibility phase - conceptual closure objectives, design criteria and activities

\begin{tabular}{|c|c|c|c|}
\hline $\begin{array}{l}\text { Project } \\
\text { Feature }\end{array}$ & Closure Objective/s & $\begin{array}{l}\text { Closure Design Criteria } \\
\text { and Constraints }\end{array}$ & Conceptual Closure Activities \\
\hline $\begin{array}{l}\text { Mine pit } \\
\text { and } \\
\text { surrounds }\end{array}$ & $\begin{array}{l}\text { Establish post-mining } \\
\text { landforms that will } \\
\text { remain in a safe, stable, } \\
\text { sustainable and non- } \\
\text { polluting condition and } \\
\text { are aesthetically } \\
\text { compatible with the } \\
\text { surrounding landscape. } \\
\text { - Relinquish the site in a } \\
\text { condition that minimises } \\
\text { risks to human health or } \\
\text { safety or to the natural } \\
\text { environment. } \\
\text { No ongoing } \\
\text { contaminated site } \\
\text { management is required } \\
\text { beyond five years post- } \\
\text { closure. } \\
\text { Discourage public } \\
\text { access to pit void. }\end{array}$ & $\begin{array}{l}\text { Pits will remain open to } \\
\text { avoid sterilisation of future } \\
\text { resources occurring within } \\
\text { the unweathered primary } \\
\text { zone. } \\
\text { - Establish an abandonment } \\
\text { bund around the perimeter } \\
\text { of an open void in } \\
\text { accordance with DMP } \\
\text { Guidelines for Safety Bund } \\
\text { Walls around Abandoned } \\
\text { Open Pits (DMP, 1997). }\end{array}$ & $\begin{array}{l}\text { Clear vegetation and topsoil from all } \\
\text { disturbed areas and directly return to } \\
\text { areas available for rehabilitation. } \\
\text { Surplus topsoil to be stored in low } \\
\text { (e.g. } 2 \text { m) stockpiles for later use in } \\
\text { rehabilitation. } \\
\text { - Progressively construct abandonment } \\
\text { bund outside of the zone of instability } \\
\text { using suitably competent waste rock } \\
\text { material produced through mining } \\
\text { (> } 2 \text { m height, }>5 \text { m base), zone of } \\
\text { instability to be determined by } \\
\text { qualified geotechnical engineer. } \\
\text { - Leave pit ramps in place so that local } \\
\text { fauna can access the water that will } \\
\text { collect in bottom of pit. } \\
\text { Rip compacted areas within the } \\
\text { abandonment bund to encourage } \\
\text { natural re-growth of native plant } \\
\text { species. } \\
\text { Remove all infrastructure and scrap } \\
\text { material from pit area and surrounds. } \\
\text { Erect signs around abandonment bund } \\
\text { wall stating public risk and prohibiting } \\
\text { public access. }\end{array}$ \\
\hline $\begin{array}{l}\text { Waste } \\
\text { dumps/ } \\
\text { stockpiles }\end{array}$ & $\begin{array}{l}\text { Establish post-mining } \\
\text { landforms that will } \\
\text { remain in a safe, stable, } \\
\text { sustainable and non- } \\
\text { polluting condition and } \\
\text { are aesthetically } \\
\text { compatible with the } \\
\text { surrounding landscape. } \\
\text { - Relinquish the site in a } \\
\text { condition that minimises } \\
\text { risks to human health or } \\
\text { safety or to the natural } \\
\text { environment. } \\
\text { - Establishment of } \\
\text { sustainable vegetation } \\
\text { communities consistent } \\
\text { with the agreed post- } \\
\text { closure land use. } \\
\text { Minimise erosion and } \\
\text { sediment release to the } \\
\text { surrounding } \\
\text { environment. } \\
\text { Minimise the release of } \\
\text { dust from the waste } \\
\text { landforms. }\end{array}$ & $\begin{array}{l}\text { - Construct to blend in with } \\
\text { surrounding natural } \\
\text { topography. } \\
\text { - Waste dumps should not be } \\
\text { higher than surrounding } \\
\text { topography (e.g. } 30 \mathrm{~m} \text { ). } \\
\text { - Minimise runoff from the } \\
\text { upper surface and outslopes } \\
\text { of the waste landform by } \\
\text { maximising infiltration. } \\
\text { - Concave upper surface with } \\
\text { low bund set back from } \\
\text { crest. } \\
\text { - Final batters }<20^{\circ} \text { overall. } \\
\text { - Avoid use of vertical drains } \\
\text { and drop structures. } \\
\text { Toe drain/bund at base of } \\
\text { waste landform to collect } \\
\text { sediment. } \\
\text { Reinstate drainage adjacent } \\
\text { to the waste landform with } \\
\text { the incorporation of site- } \\
\text { specific drainage/sediment } \\
\text { control measures. }\end{array}$ & $\begin{array}{l}\text { Clear vegetation and topsoil from all } \\
\text { disturbed areas and directly return to } \\
\text { areas available for rehabilitation. } \\
\text { Surplus topsoil to be stored in low } \\
\text { (e.g. } 2 \text { m) stockpiles for later use in } \\
\text { rehabilitation. } \\
\text { - Progressively batter waste landform } \\
\text { and shape to meet design criteria. } \\
\text { - Topsoil to be spread over all disturbed } \\
\text { areas to an optimum depth of } 100 \mathrm{~mm} \text {. } \\
\text { - Re-spread stockpiled vegetation } \\
\text { material. } \\
\text { - Deep rip (maximum } 1 \text { m depth) along } \\
\text { contour. } \\
\text { - Seed with local native species. } \\
\text { Develop appropriate completion } \\
\text { criteria. } \\
\text { Monitor erosion and progress of } \\
\text { rehabilitation to ensure completion } \\
\text { criteria are met. }\end{array}$ \\
\hline
\end{tabular}




\subsection{Detailed engineering design and construction}

The conceptual closure plan will be used throughout the detailed engineering design and construction phase of the project to incorporate objectives and closure activities in design and construction. Operational project management plans are also developed at this stage. The project construction phase is usually the first point in the life of a project where experience is gained on how mined materials and disturbed areas actually behave under varying seasonal conditions.

\subsection{Operations}

The first one to two years of a mining operation represent a steep learning curve for the project operators. It is therefore important to work within the broad closure objectives applying the conceptual closure design criteria. Consistent with the Strategic Framework for Mine Closure (ANZMEC and MCA, 2000) a preliminary closure plan should be developed during this time with several subsidiary plans including: rehabilitation plan; decommissioning plan; and a maintenance and monitoring plan.

The preliminary closure plan needs to provide detailed completion criteria specifying required outcomes for all areas disturbed and waste landforms constructed to date based on the information gained through operational experience. In some cases, this may include revising previous design criteria. For example, if signs of significant erosion are evident on waste landform batters which have been constructed to $20^{\circ}$ as per design criteria, a lower slope angle should be considered for the landforms. Conversely, if the material proves to be more competent than previously determined a case may be made to increase the slope angles.

The concept of adaptive management must also be applied to setting completion criteria throughout the mine life. Adaptive management is defined by the Leading Practice Sustainable Development Program for the Mining Industry - Mine Closure and Completion booklet (DITR, 2006) as:

"A systematic process for continually improving management policies and practices by learning from the outcomes of operational programs".

The (ICMM, 2006) Good Practice Guidance on Mining and Biodiversity refers to adaptive management as:

"do-monitor-evaluate-revise".

It is also important to commence progressive rehabilitation and rehabilitation trials as early as possible during the project mine life to determine what vegetation species are most appropriate and functional for achieving closure outcomes. It may be many years (e.g. 5-10) into the mine life before it is possible to assess the success of rehabilitation in achieving the most practicable criteria in terms of ecosystem function and/or landform stability. The highest level of completion criteria such as vegetation species distribution and density can only be based on actual monitoring of trials or other local experience with similar materials and climatic conditions.

\section{Summary and conclusion}

In conclusion, appropriate closure criteria must be developed throughout the life of a mining operation based on experience and information gained throughout the project. The level of accuracy of closure cost estimations at any stage of an operation is also dependent on the level of certainty of the completion criteria (Table 3). 
Table 3 Accuracy of closure cost estimates in relation to stage of mine life

\begin{tabular}{|c|c|c|}
\hline Stage of Operations & Basis for Setting Completion Criteria* & $\begin{array}{l}\text { Closure Cost Estimate } \\
\text { Reliability* }\end{array}$ \\
\hline $\begin{array}{l}\text { Acquisition/ } \\
\text { exploration/ } \\
\text { feasibility }\end{array}$ & $\begin{array}{l}\text { - Experience with previous local mining activity. } \\
\text { - Existing land tenure and land use. } \\
\text { - toponeral environmental characteristics i.e. climate, } \\
\text { - Orebody characteristics (from exploration } \\
\text { drilling). }\end{array}$ & $\begin{array}{l}\text { Order of magnitude } \\
\pm 50-100 \%\end{array}$ \\
\hline $\begin{array}{l}\text { Definitive } \\
\text { feasibility }\end{array}$ & $\begin{array}{l}\text { - Conceptual closure plan. } \\
\text { - Project design engineering. } \\
\text { - Resource estimation and preliminary mine } \\
\text { schedule based on infill drilling results and } \\
\text { optimisation studies. } \\
\text { - Baseline environmental studies. } \\
\text { - Materials characterisation. } \\
\text { - Stakeholder consultation. }\end{array}$ & $\begin{array}{l}\text { Variable } \\
\pm 30-50 \%\end{array}$ \\
\hline $\begin{array}{l}\text { Detailed } \\
\text { engineering design/ } \\
\text { construction }\end{array}$ & $\begin{array}{l}\text { - Accumulated information and operational } \\
\text { experience from all of above, plus: } \\
\circ \text { Detailed engineering design. } \\
\circ \text { Materials handling. } \\
\circ \text { Continuous presence on-site. }\end{array}$ & $\pm 25-40 \%$ \\
\hline $\begin{array}{l}\text { One to two years } \\
\text { following } \\
\text { commencement }\end{array}$ & $\begin{array}{l}\text { - Accumulated information and operational } \\
\text { experience from all of above, plus: } \\
\circ \text { Preliminary closure plan. } \\
\circ \text { Adaptive management. } \\
\circ \text { Commencement of progressive rehabilitation } \\
\text { and trials. }\end{array}$ & $\pm 15-30 \%$ \\
\hline $\begin{array}{l}\text { Five to ten years } \\
\text { following } \\
\text { commencement }\end{array}$ & $\begin{array}{l}\text { - Accumulated information and operational } \\
\text { experience from all of above, plus: } \\
\circ \text { Adaptive management. } \\
\circ \quad \text { Results from rehabilitation and trial } \\
\text { monitoring. }\end{array}$ & $\pm 10-15 \%$ \\
\hline $\begin{array}{l}\text { Immediately prior } \\
\text { to shutdown } \\
\text { (<1 year) }\end{array}$ & $\begin{array}{l}\text { - Accumulated information and operational } \\
\text { experience from all of above, plus: } \\
\circ \text { Adaptive management. } \\
\circ \text { Quoted costs for major elements of } \\
\text { decommissioning. }\end{array}$ & $< \pm 15 \%$ \\
\hline
\end{tabular}

*(estimated with reference to Allen, 2000)

\section{References}

Allen, B. (2000) Case Study 3 - Homestake, Proceedings of Seminar entitled Planning for Mine Closure - An Operators Guide, 7-8 December 2000, Perth, Australia, Australian Centre for Geomechanics, Perth, S8, 9 p.

Australian and New Zealand Minerals and Energy Council and Minerals Council of Australia (ANZMEC and MCA) (2000) Strategic Framework for Mine Closure, Canberra, Australia. 
Department of Industry, Tourism and Resources (DITR) (2006) Leading Practice Sustainable Development Program for the Mining Industry - Mine Closure and Completion, Canberra, Australia, $53 \mathrm{p}$.

Department of Mines and Petroleum (DMP) (1997) Guidelines for Safety Bund Walls Around Abandoned Open Pit Mines, Government of Western Australia, Department of Industry and Resources, 14 p., viewed 20 June 2009, http://www.dmp.wa.gov.au/documents/Guidelines/MSH_G_SafetyBundWallsAroundAbandonedMines.pdf.

International Council on Mining and Metals (ICMM) (2006) Good Practice Guidance on Mining and Biodiversity, London, UK, S5.3.6, 71 p. 